\title{
Influence of Tax Examination to Compulsory Tax Compatibility in the Corporate of South Makassar KPP Pratama
}

\author{
Ishak Hamzah $^{1^{*}}$, Haliah ${ }^{2}$, Harryanto ${ }^{2}$ and Kartini ${ }^{2}$ \\ ${ }^{1}$ College of Economics Bongaya Makassar, Indonesia
}

${ }^{2}$ Hasanuddin University, South Sulawesi, Indonesia

"Corresponding author: Ishak Hamzah, College of Economics Bongaya Makassar, Indonesia, Tel: +62 411 586200; E-mail: ishakhamzah476@yahoo.com

Received Date: May 31, 2018; Accepted Date: Jun 28, 2018; Published Date: Jul 04, 2018

Copyright: ${ }^{\odot} 2018$ Hamzah I, et al. This is an open-access article distributed under the terms of the Creative Commons Attribution License, which permits unrestricted use, distribution, and reproduction in any medium, provided the original author and source are credited.

\begin{abstract}
This study aimed to determine the effect of the Tax Inspection of the Ke compliance taxpayer on STO South Makassar. Respondents in this study are taxpayer Agency totaling 100 samples registered on KPP Pratama Makassar Selatan. Hypothesis in this research use simple linear regression. Data collection used the primary data obtained from the questionnaire using the slovin formula. The results of this study indicate that tax hamming has a positive and significant effect on Taxpayer Compliance Agency at KPP Pratama Makassar Selatan. More precisely this result is supported by the result of calculation of comparison $t_{\text {arithmetic }}$ with $t_{\text {table }}$, obtained value $t_{\text {count }} 3.449>$

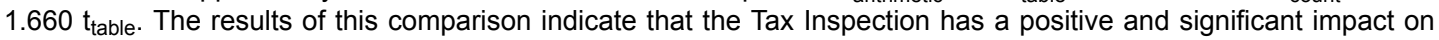
Taxpayer Compliance in KPP Pratama Makassar.
\end{abstract}

Keywords: Tax inspection; Corporate taxpayer compliance; E-filing

\section{Introduction}

\section{Background}

Seiring with the development of science and technology, especially in the case of computerization and internet world, the Directorate General of Taxation adopted a new technological innovation of internet technology to serve as one of the tools that facilitate the taxpayer in fulfilling his tax obligations. B the form of internet-based taxation service 243/PMK.03/2014 is the application of e-filing system, namely service delivery of the Notice of Period (SPT Masa) and Annual Tax Return (SPT Tahunan) in the form of electronic form in computer media. SPT is not in the form of paper, but in the form of electronic forms transferred or submitted to the Directorate General of Taxes through the Tax Office with an integrated and real time process [1].

In the decision of the Director General of Taxes No. KEP-88/PJ./ 2004 dated May 14, 2004 concerning the Submission of Electronic Information Letter, it is stated that the e-SPT submission is done through the Application Service Provider (Perusahaan Pengedia Aplikasi Aplikasi) appointed by the Director General Pa. For further settings then Government issued Decree On rektur General of Taxation Number KEP-05/PJ./2005 dated January 12, 2005 among Procedures for Submission of Notice in Electronics (e-Filing) through Jasa Applications Provider (ASP).

Basically the delivery of SPT e-filing is an attempt of the Directorate General of Taxation to provide convenience services for the Taxpayer in reporting the amount of taxes that must be paid. Because Taxpayers do not need to come directly to the Tax Office to meet the tax obligations in terms of delivery of SPT. As for Tax Officers, e-filing technology is able to facilitate them in database management because the storage of taxpayer documents has been done in digital form. With this technology the Government expects the increase in taxpayer compliance in the implementation of tax obligations.

And on January 24, 2005 coincides at the Presidential Office in, the President of the Republic of Indonesia together with the Directorate General of Pajak launches e-Filing or Electronic Filing System i.e., tax filing/delivery system with electronic notification (SPT) Filing) is done through a real-time on-line system.

Data that we get at information system of Directorate General of Tax (DJP), submission of Annual Tax Return of Personal Tax of 2015 through e-Filing is $2,469,572$ SPT. When compared to the same period in the previous year amounted to $1,081,164$ SPT. While the submission of Annual Income Tax Personal Income in 2015 through manual is a number of 6,429,925 and Anwar Pohan [2] in the year 2014 is a number of $6,510,408$. The current number of active 2015 Personal Taxpayers totaling 74,031, the current number of non-current 2015 Individual Taxpayers totals 18,071 total numbers of individual Personal Tax Payers totaling 92,102.

The use of e-filing is intended to enable the Taxpayer to obtain easiness in fulfilling its obligations, so that the fulfillment of tax obligations can be more easily implemented and the goal to create a more orderly and transparent tax administration can be achieved. Dewi also revealed that the main purpose of e-filing reporting is to reduce the cost and time of the Taxpayer to prepare process and report the Tax Return (LAT) to the Tax Office (KPP) correctly and on time [3].

The phenomenon that occurs in Indonesia is still the lack of taxpayers who use e-filing application, whereas the application issued by the Directorate General of Taxes is spelled out to facilitate the taxpayer reported his Notice (SPT) [4]. Taxpayers still prefer to use the Notice Manually instead of e-filing. Taxpayers are still worried about using e-filing when delivering an annual SPT in large quantities. The main problem if at any time the internet experience error or down so that data is not recorded, lost and it is not included in the database Directorate of Gender all Taxes [5]. 
This research is a follow-up of some research that has been done before, such as research conducted by Cih Laihad Research conducted with the title of the influence of taxpayer behavior toward the use of efiling taxpayer in Manado city. And also research conducted by Aulia Dyanrosi analysis of personal taxpayer behavior against behavioral interest using e-filing.

\section{Problem formulation}

$\mathrm{M}$ is which can be identified in this study, namely: 1) Does the taxpayer's behavior on the perception of e-filing usefulness affect the use of e-filing? 2) Does the taxpayer's behavior on perception ease of efiling affect the use of e-filing?; 3 ) Is there any influence of taxpayer behavior on perception of usability and perception ease of e-filing simultaneously to the use of e-filing?

\section{Theoretical Review}

\section{Understanding tax}

Rochmat Soemitro in Mardiasmo [6] argues that Tax is a transition from the people to the state treasury to finance routine expenditures and its "surplus" is used for public saving which is the primary source to finance public investment.

According to Djajadiningrat in the Official Siti states, Tax as an obligation to surrender some of the wealth to the state treasury due to a circumstance, occurrence, and deeds that give a certain position, but not as punishment, according to the rules established by the government and can be forced, but there is no direct reciprocal service from the state, to buy general welfare nutrients.

Feldmann in the Official Siti says: Taxes are unilaterally enforced achievements oh and owed to the authorities (according to the norms he sets out in general), without the absence of contrapret, and are solely used to cover general expenses. "

\section{Types of taxes}

P invite can be grouped into three (3) sections: 1) Taxes according to the Group which is entitled to the Direct Tax, i.e., the tax which shall be borne by the taxpayer and the imposition thereof shall not be delegated to another party, and the Indirect Tax, i.e., the tax which the imposition may be delegated to the other party; 2) Taxes According to Nature, consisting of a Subjective Tax, namely taxes that are based or based on the subject and subsequently sought objective terms, in the sense of paying attention to the taxpayer's personal circumstances, and the objective tax, i.e., tax based on the object, regardless of the taxpayer's self; 3) Taxes according to the Institute of the Collector consists of the Central Tax, the tax levied by the central government and used to finance the state households, and the Local Taxes, the taxes levied by the government and used to finance local households [7].

\section{Behavior}

According Adrianto Sugiarto Human behavior is the result of all kinds of experience and human interaction with the environment manifested in the form of knowledge, attitudes and actions [8]. In other words, behavior is the response/reaction of an individual to the stimulus that comes from outside or from within himself. This response can be passive (without action: thinking, arguing, being) or active (taking action). In accordance with these limitations, health behavior can be formulated as a form of individual experience and interaction with the environment, especially with regard to knowledge and attitudes about health. Active behavior can be seen, whereas passive behavior does not appear, such as knowledge, perception, or motivation. Some experts distinguish the forms of behavior into three domains of knowledge, attitude, and action or often we hear with the term knowledge, attitude, and practice.

According to Miladia the theory of Planned Behavior explains that the behaviors displayed by the individual arise because of the intention to behave While the intention appears to behave determined by 3 determinant factors: (1) behavioral beliefs, i.e., individual beliefs will result from beliefs strength and outcome evaluation, (2) normative beliefs, i.e., beliefs about others' normative expectations and normative beliefs and motivation to comply, and (3) control beliefs, i.e., beliefs about the existence of things that support or inhibit the behavior that will be displayed (control beliefs) and perceptions about how strong things that support and inhibit their behavior (perceived power) [9]. In the Theory of Planned Behavior formulated by Ajzen (Ernawati 6 and Purnomosidhi, 2010), the intention of behaving is the intermediate variable in shaping behavior. This means that a person will perform an action or behavior through intent [10].

\section{Technology Acceptance Model (TAM)}

Technology Acceptance Model (TAM) is one of the theories about the use of information technology systems that are considered very influential and generally used to explain the individual acceptance of the use of information technology systems. This theory was first introduced by Davis. This theory was developed from Theory of Reasoned Action or TRA by Ajzen and Fishbein.

Primary reveals the acceptance of users or users of information technology to be part of the research of the use of information technology, because prior to use and known success, first be sure about acceptance or rejection of the use of information technology. The acceptance of information technology users is closely related to the variation of user problems and potential benefits received if information technology is applied in user activities in connection with taxation activities [11].

\section{E-filing}

According to the DGT Regulation No. PER-1/PJ/2014 Article 1 (6), e-filing is a way of delivering tax return or delivery of Renewal Notice the annual tax return electronically conducted online in real time via the website of the Directorate General of Taxes (www. tax.go.id) or Application Service Provider (ASP) [12]

Putra (2015) explains that the purpose of tax reporting e-Filing namely: 1) Assist taxpayers to provide facilities SPT reporting electronically via the internet to taxpayers so that taxpayers can do it anywhere and anytime; 2) Provide support to the Tax Office (KPP) Regulation Number PER-26/PJ/2012 in the case of SPT reports received quickly and streamlining administrative activities, data collection, distribution, and filing of SPT reports; 3) Increase the number of taxpayers who report their tax amount and increase the amount of State income from taxes [13].

According to Nur (2009), with so many advantages of SPT delivery system with e-filing application, there are still weaknesses that must be considered include: 1) On paper, the transfer of conventional tax reporting to digital reporting looks easy. But in the field can occur 
various problems. In the early stages of implementation of this system in the KPP under the Regional Office of Special DGT and DGT Office of Large Tax Payers upload data often fail. The delivery of digital SPT through internet is often jammed, so Taxpayers often deliver their digital SPT in the form of floppy disk directly to KPP; 2) Access internet connection line in Indonesia that still not optimal. Internet connection in Indonesia is sometimes slow and even disconnected, so when the taxpayer will upload SPT data with the application and then disconnected, then the Taxpayer must repeat from the beginning. This is greatly felt by many taxpayers who have applied e-filing; 3) Real conditions in the field, outside the KPP under the Special Regional Office of DGT and DGT Office of Large Taxpayers, awareness of Taxpayers to use the application is still very low.

\section{Research Methods}

This research uses descriptive method. According to Nur Indriantoro (2013: 26), descriptive research is a study of the problems of the current facts of a population. The purpose of descriptive research is to test the hypothesis or answer questions related to the current status of the subject under study. This type of research is generally related to opinion (individual, group, or organizational), event or procedure. This research will be conducted in Tax Office Pratama Makassar West at City Hall N o.15, Makassar. Penelitian this was conducted in June tahun 2017201 years until August 7.

\section{Population and sample}

Population is a generalization area consisting of objects/subjects that have certain qualities and characteristics set by researchers to be studied and then drawn conclusions [14].

The population in this study is the total number of individual taxpayers registered in the Tax Office Pratama West Makassar until 2015, which amounted to 92,102 .

Sugiyono states that the sample is part of the number and characteristics possessed by the population tersebut. In this study using the Incidental Sampling because the collection of sample members by chance, i.e., anyone who by chance/incidental meet with the researchers can be used as a sample, when viewed by the person who happened to meet it is suitable as a source of data [14].

Based on data from West Makassar KPP until early in 2015, there were 92,102 individual taxpayers. Therefore, the number of samples for research with a margin of error of $10 \%$ is 99.99 which is rounded to 100 individual taxpayers.

\section{Datacollectionand analysistechniques}

Primary data collection is done by survey method using questionnaire media. A number of questions will be asked to respondents and then respondents are asked to answer in accordance with their opinion. To measure the respondent's opinion, the five-digit Likert scale is used, starting from the number 5 for the opinion of strongly agree (SS) and the number 1 for the opinion strongly disagree (STS) [15]. Analysis of the data used to test the hypothesis in this study is using multiple linear regression model.

\section{Results}

\section{Identity of respondents}

The populations in this study are taxpayers registered at the Tax Office Pratama West Makassar. The sampling technique used is incidental sampling. From Basu Swastha and Irawan. Data collection in this study was conducted by distributing questionnaires to taxpayer respondents registered at the Tax Office Pratama West Makassar. The process of distributing the questionnaire was conducted for less than two months [16].

Samples taken in this study amounted to 100 respondents. The number of questions each questionnaire contains 11 statement items. Statement for usability perception variable (X1) is 3 statements, for ease perception variable (X2) as much as 5 statement and for efiling variable (Y) 3 statements.

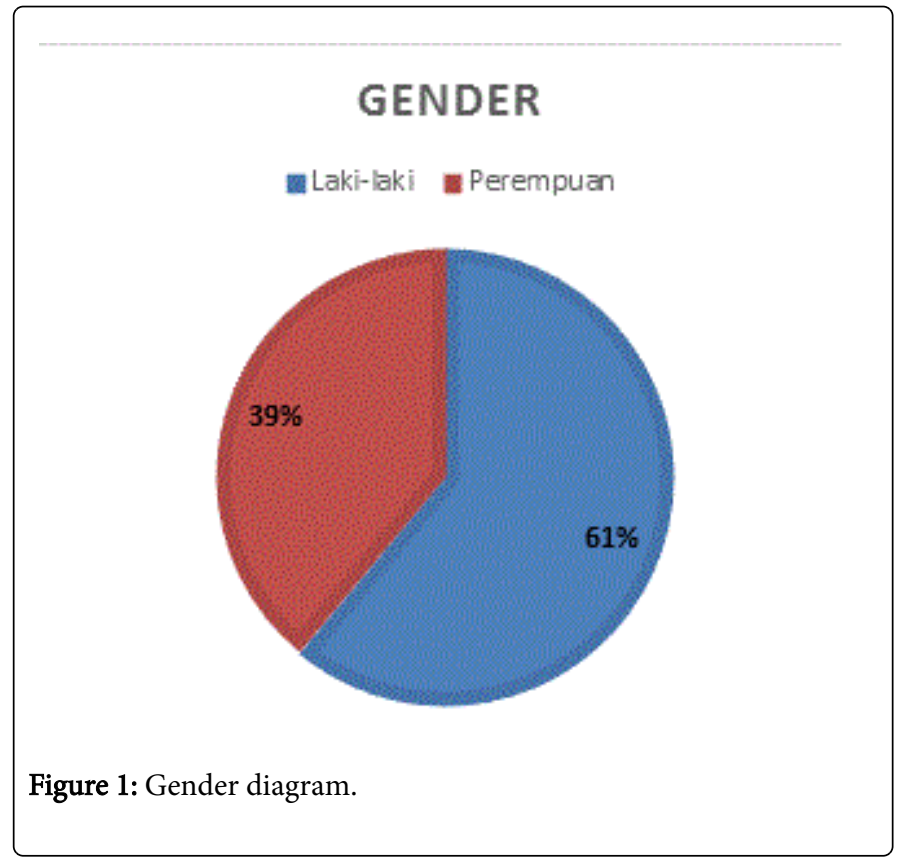

Based on the above Figure 1 gender of 100 respond en, the number of men as 61 people or $61 \%$ and the remaining 39 people or $39 \%$ are women. This Figure shows that the majority of respondents are male.

Based on the below Figure 2 age, out of 100 respondents aged $<25$ years, 36 respondents at $36 \%$, for ages $25-35$ years were 46 respondents or $46 \%$, and for $36-45$ years old, 18 respondents or $18 \%$. This Figure indicates that the majority of respondents are aged 25-35 years.

\section{Validity and reliability test results data}

Validity test: The validity of an instrument is shown by its ability to measure what it should measure. Similarly, research questionnaires. The research questionnaire is said to be valid if the instrument is really able to measure the value of the variables studied. Decisions on a statement item can be considered valid if the coefficient of product moment correlation exceeds 0.30 and vice versa if below 0.30 is considered invalid.Validity testing is done with SPSS program. The following test results are validity for each statement of usability perception variable (X1) (Table 1). 
Page 4 of 7

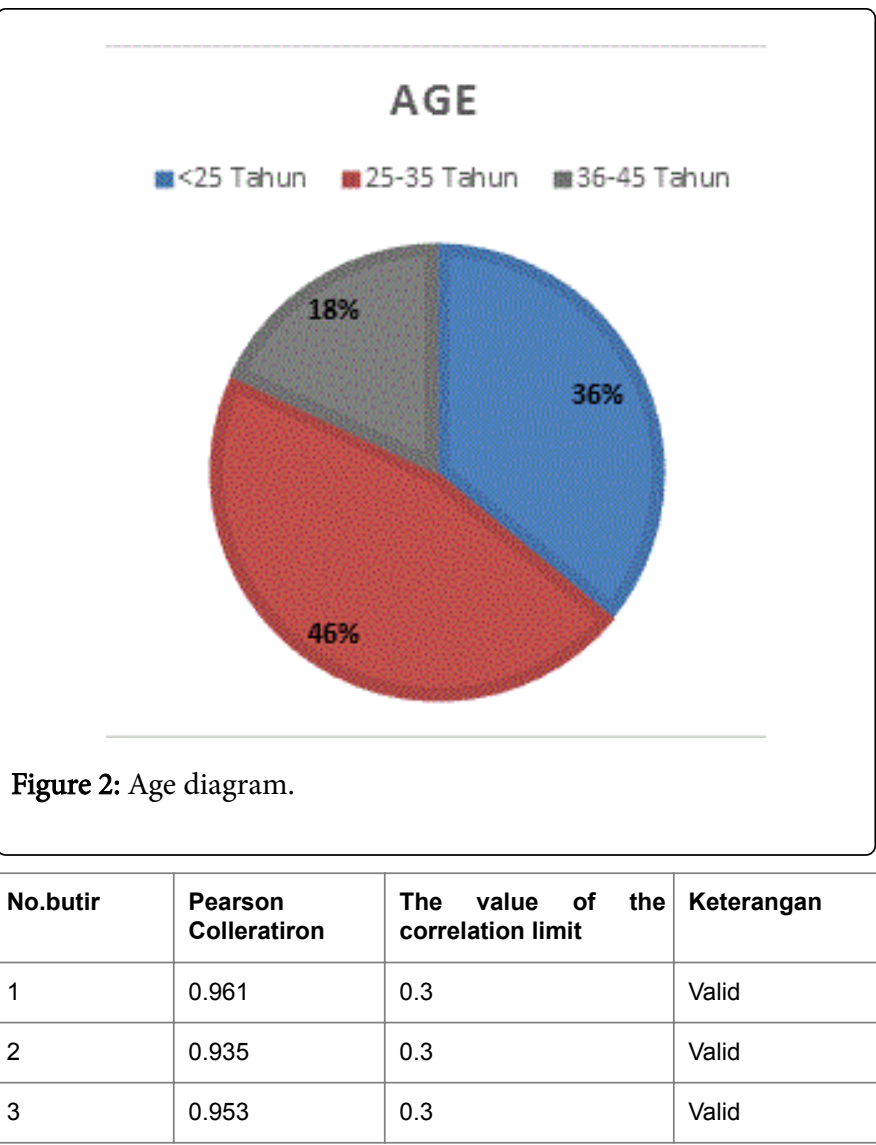

Table 1: Validity test of perception variable usability.

Based on the results of the validity test presented in the above Table 1, the Product Moment coler value for each item of variable X1 is greater than the value of the coefficient of correlation (r-count) is 0.30. It can be concluded that each statement item on the variable indicator Perceptions of Use (X1) is valid. Test results for each item of convenience perceptual variable statement (X2) (Table 2).

\begin{tabular}{|l|l|l|l|}
\hline No.butir & Pearson Colleratiron & $\begin{array}{l}\text { The value of the } \\
\text { correlation limit }\end{array}$ & K eterangan \\
\hline 1 & 0.845 & 0.3 & Valid \\
\hline 2 & 0.867 & 0.3 & Valid \\
\hline 3 & 0.929 & 0.3 & Valid \\
\hline 4 & 0.92 & 0.3 & Valid \\
\hline 5 & 0.926 & 0.3 & Valid \\
\hline
\end{tabular}

Table 2: Test of convenience perception validity.

Based on the results of the validity test presented in the above Table 2, the value of Product Moment coleration for each item of variable $\mathrm{X} 2$ is greater than the value of the coefficient of correlation ( $\mathrm{r}$-count) is 0.30 . It can be concluded that each statement item in the Eight Perception variable indicator (X2) is valid. Then the following test results for each item statement variable Use e-filing (Y) (Table 3).

\begin{tabular}{|l|l|l|l|}
\hline No.butir & Pearson Colleratiron & $\begin{array}{l}\text { The value of the } \\
\text { correlation limit }\end{array}$ & Keterangan \\
\hline 1 & 0.925 & 0.3 & Valid \\
\hline 2 & 0.924 & 0.3 & Valid \\
\hline 3 & 0.923 & 0.3 & Valid \\
\hline
\end{tabular}

Table 3: Test validity use of E-filing.

Based on the results of the validity test presented in the above Table 3 , the product moment correlation value for each item of variable $\mathrm{Y}$ is greater than the value of the coefficient of correlation ( $r$-count) is 0.30 . Thus it can be concluded that all statement items on the variable indicator Use of E-filing $(\mathrm{Y})$ is declared valid.

Test reliability: In this reliability test, the researcher uses the value of cronbach's alpha. If the value of cronbach's alpha is greater than 0.60 then the questionnaire is said to be reliable. This reliable test uses the SPSS program. Here are the test results for each item of the research variable statement (Table 4).

\begin{tabular}{|l|l|l|}
\hline Variables & $\begin{array}{l}\text { Cronbach's } \\
\text { Alpha }\end{array}$ & Information \\
\hline Perceptions of Use (X1) & 0.945 & Reliable \\
\hline Perception of Convenience (X2) & 0.940 & Reliable \\
\hline Use of E-filing (Y) & 0.913 & Reliable \\
\hline
\end{tabular}

Table 4: Test reliability of research variables.

Based on the results of reliability test presented in the Table 4 above, shows that all the variables used as items in this study has a good level of reliability. This is seen from the test results, cronbach's alpha value of each variable above 0.60 so it can be concluded that the questionnaire on each variable in this study can be trusted.

\section{Classic assumption test}

Normality test: Normality test aims to test whether in the variable regression model has a normal distribution. Normality test in this study using Kolmogorov-Smirnov non-parametric statistical test. 74 / PMK.03 / 2012 Variables are said to be normal distributions if the Kolmogorov-Smirnov value has a significant level greater than 0.05 [17]. Based on the results of Kolmogorov Smirnov test in the above Table 4 that shows the value of significance level / profitability (Asymo Sign) with Kolmogorov Smirnov value of 0.73 this means above the level of significance of $5 \%$ or $(0.05)$. So it can be concluded that the residual data is normally distributed and the regression model meets the classical assumption.

Test multicollinearity: The multicollonierity test can be seen from the tolerance value and the opponent Variance inflation factor (VIF). A regression model can be said to be free of Multicollinearity if the Multicollinearity test results obtained VIF value less than 10 and Tolerance more than 0.10 (Table 5).

Based on the above Table 5 Multicollinearity Test, it is known that the Tolerance Value of Usability Perception (X1) and the Convenience Perception (X2) that is 0.375 is greater than 0.10 . Meanwhile, the VIF value of usability perception variable (X1) and convenience perception 
Citation: Hamzah I, Haliah, Harryanto, Kartini (2018) Influence of Tax Examination to Compulsory Tax Compatibility in the Corporate of South Makassar KPP Pratama. J Glob Econ 6: 296. doi:10.4172/2375-4389.1000296

Page 5 of 7

(X2) is 2.670 smaller than 10.00 . So it can be concluded does not occur Multikolonieritas.

\begin{tabular}{|l|l|l|}
\hline Model & \multicolumn{1}{|l|}{ Collinearity Statistics } & \\
\hline & Tolerance & VIF \\
\hline Perception of use & 375 & 2,670 \\
\hline Perceptions working & 375 & 2,670 \\
\hline
\end{tabular}

Table 5: Multicollonearity test results.

Heteroscedasticity test: Hetero $\mathrm{s}$ kedastisitas test aims to test whether the regression model occurred inequality variance from one observation to another observation. A good regression model is Homocedasticity or Heterocedasticity does not occur. To detect the presence or absence of heterokedastisitas done with Test Glejser (Table 6).

Based on the above Table 6 Heteroskedasticity Test it is known that the value of significance $n$ the variable of usability perception (X1) is 0,665 bigger than 0,05 , meaning there is no heteroskedastisitas on usability perception variable (X1), whereas in variable of perception ease (X2) 0,716 bigger than 0.05, meaning there is no heteroskedastisitas on variables ease the perception of ease (X2).

\begin{tabular}{|c|c|c|c|c|c|}
\hline \multicolumn{6}{|c|}{ Coefficients $^{a}$} \\
\hline \multirow{2}{*}{ Model } & \multicolumn{2}{|c|}{ Unstandardized Coefficients } & \multirow{2}{*}{$\begin{array}{c}\begin{array}{c}\text { Standardized } \\
\text { Coefficients }\end{array} \\
\text { Beta }\end{array}$} & & \multirow{2}{*}{ Sig. } \\
\hline & B & Std. Error & & & \\
\hline 1 (Constant) & 0.323 & 0.196 & & 1.646 & 0.103 \\
\hline Perception of use & 0.031 & 0.071 & 0.072 & 0.434 & 0.665 \\
\hline Perceptionsworking & -0.027 & 0.074 & -0.060 & -0.365 & 0.716 \\
\hline
\end{tabular}

Table 6: Heteroscedasticity test results.

\section{Discussion}

\section{Descriptive statistics analysis}

Descriptive statistical analysis of data used to provide a description of the spread of data research variables are Perception Uses (X1)
Perception Ease (X2) and Penggunana E-filing (Y) has done well (Table 7).

\begin{tabular}{|l|l|l|l|l|l|l|l|l|l|}
\hline Descriptive Statistics & N & Range & Minimum & Maximum & Sum & Mean & Std. Deviation \\
& Statistic & Statistic & Statistic & Statistic & Statistic & Statistic & Std. Error & Statistic \\
\hline Perception of use & 100 & 4 & 1 & 5 & 431.66 & 4.3166 & 0.07851 & 0.78511 \\
\hline Perceptionsworking & 100 & 3.8 & 1.2 & 5 & 392.4 & 3.924 & 0.07531 & 0.75306 \\
\hline E-filing & 100 & 4 & 1 & 5 & 395.66 & 3.9566 & 0.07366 & 0.73661 \\
\hline Valid N (listwise) & 100 & & & & & & & \\
\hline
\end{tabular}

Table 7: Descriptive statistics of research variables.

Based on Table 7 above, it can be seen that the mean value (mean) variable Perception Use (X1) 4.3166 greater than standard deviation 0.78511 , this indicates that the spread of perceptual variable data variable good use.

In the convenience perception variables (X2) 3.9240 greater than the standard deviation of 0.75306 , this shows that the spread of perceptual data variable perception of goodness. Likewise with the average value (mean) variable use of e-filing (Y) 3.9566 greater than standard deviation 0.73661 which means the data is well distributed.
It can thus be gathered that the distribution of data on perceptual instruments of usefulness, ease of perception and the use of e-filing is said to be good because the mean value of each instrument is greater than the standard deviation.

\section{Inferential statistics analysis}

Inferential statistics are the statistics used to descriptive the sample data and the results will be generalized to the population in which the 
Citation: Hamzah I, Haliah, Harryanto, Kartini (2018) Influence of Tax Examination to Compulsory Tax Compatibility in the Corporate of South Makassar KPP Pratama. J Glob Econ 6: 296. doi:10.4172/2375-4389.1000296

Page 6 of 7

sample is taken. Inferential analysis used in this research is multiple linearregression analysis (Table 8).

This method shows that the regression coefficient of the estimated result is positive. This result gives an illustration that there is a positive correlation between usability perception variable and perception of ease of e-filingwhich means that the increasing perception of usability and perception of ease on the taxpayer will increase the use of e-filing system.

\begin{tabular}{|c|c|c|c|c|c|c|c|c|c|}
\hline \multicolumn{10}{|c|}{ Model Summary } \\
\hline \multirow[t]{2}{*}{ Model } & \multirow[t]{2}{*}{$\mathbf{R}$} & \multirow[t]{2}{*}{ R Square } & \multirow[t]{2}{*}{ Adjusted R Square } & \multirow[t]{2}{*}{$\begin{array}{l}\text { Std.Error of } \\
\text { the Estimate }\end{array}$} & \multicolumn{5}{|c|}{ Change Statistics } \\
\hline & & & & & $\begin{array}{l}\text { R Square } \\
\text { Change }\end{array}$ & F Change & df1 & df2 & $\begin{array}{l}\text { Sig. } F \\
\text { Change }\end{array}$ \\
\hline 1 & $0.751^{\mathrm{a}}$ & 0.564 & 0.555 & 0.49129 & 0.564 & 62778 & 2 & 97 & 0.000 \\
\hline \multicolumn{10}{|c|}{ Predictors: (Constant), Perceptions of easy, Perception of use } \\
\hline \multicolumn{10}{|c|}{ Anova } \\
\hline \multicolumn{2}{|l|}{ Model } & \multicolumn{2}{|c|}{ Sum of Squares } & df & Mean Square & \multicolumn{2}{|l|}{$\mathbf{F}$} & \multicolumn{2}{|r|}{ Sig. } \\
\hline \multicolumn{2}{|l|}{ Regression } & \multicolumn{2}{|r|}{30,304} & 2 & 15,152 & \multicolumn{2}{|c|}{62,778} & \multicolumn{2}{|r|}{$0.000^{\mathrm{b}}$} \\
\hline \multicolumn{2}{|l|}{ Residual } & \multicolumn{2}{|r|}{23.412} & 97 & 241 & & & & \\
\hline \multicolumn{2}{|l|}{ Total } & \multicolumn{2}{|r|}{53.716} & 99 & & & & & \\
\hline \multicolumn{10}{|c|}{$\begin{array}{l}\text { aDependent variable: E-filing } \\
\text { bPredictors: (Constant), Perceptions of easy, Perception of use }\end{array}$} \\
\hline \multicolumn{10}{|c|}{ Coefficients } \\
\hline \multirow{2}{*}{ Model } & \multicolumn{2}{|c|}{$\begin{array}{l}\text { Unstandardized } \\
\text { Coefficients }\end{array}$} & $\begin{array}{l}\text { Standardized } \\
\text { Coefficients }\end{array}$ & $\mathbf{t}$ & Siq. & \multicolumn{4}{|c|}{ Collinearity Statistics } \\
\hline & B & Std.Error & Beta & Tolerance & VIF & & & & \\
\hline (Constant) & 857 & 285 & & 3.012 & 003 & & & & \\
\hline Perception of use & 281 & 103 & 299 & 2,733 & 007 & 375 & & & 2,670 \\
\hline Perceptionsworking & 481 & 107 & 492 & 4,489 & 000 & 375 & & & 2,670 \\
\hline
\end{tabular}

Table 8: Inferential statistics of research variables.

Based on the above Table 8, obtained multiple linear regression formula as follows:

$$
\mathrm{Y}=0.857+0.281 \mathrm{X} 1+0.481 \mathrm{X} 2+\mathrm{e}
$$

\section{Hypothesis testing results}

Simultaneous Hypothesis Test (F Test) Test F is used to determine whether the independent variable simultaneously affect the dependent variable. The hypothesis will be tested using a significance level of 5 percent or 0.05 . Be aware of the results if data shows that the F-count is 62.778 with a significance level of 0.000 . This shows that the significance value is smaller than the significance level of $5 \%$ $(0.000<0.05)$ and the $\mathrm{F}$ value count is greater than the $\mathrm{F}$ table value $(62.778>3.090)$ then the hypothesis is accepted. This means that the perception of usability and ease of perception have a significant positive effect on the use of e-filing.

\section{Partial test (T Test)}

$\mathrm{T}$ test is done to test the significance of the influence of each independent variable to the dependent variable. The criterion for determining that the hypothesis is accepted is if the significance value is smaller than the significance level of $5 \%$ and $t$ count is greater than $t$ table. Usability perception variable has a positive direction of 0.281 and $t$ value of 2,733 with a significance value of 0.007 . This shows that the significance value is smaller than the significance level of $5 \%$ $(0.007<0.05)$ and the value of $t$ arithmetic is greater than the value of $t$ table $(2.733>1.984)$ then the hypothesis is accepted. This means that usability perceptions significantly influence the use of e-filing. Then on the perceptual variables ease has a positive direction that is equal to 0.481 and $t$ count value 4.489 with a significance value of 0.000 . This shows that the significance value is smaller than the significance level of $5 \%(0.000<0.05)$ and the value of $t$ arithmetic is greater than the value of $t$ table $(4.489>1.984)$ then the hypothesis is accepted. This means that ease of perception significantly influence the use of e-filing.

The result of hypothesis testing for perception of usability and perception of ease of use of e-filing shows that usability perception and 
Citation: Hamzah I, Haliah, Harryanto, Kartini (2018) Influence of Tax Examination to Compulsory Tax Compatibility in the Corporate of South

Page 7 of 7

ease perception have a significant positive effect on e-filing usage. T test resultsdipeoleh positive direction of 0.281 and $t$ value of 2.733 with a significance value of 0.007 . This shows that the significance value is smaller than the significance level of $5 \%(0.007<0.05)$ and the value of $t$ arithmetic is greater than the value of $t$ table $(2.733>1.984)$.

In addition, based on the results of the coefficient of determination (R 2) of 0.564 or $56.4 \%$, which means that the variation of e-filing usage which can be explained by usability perception and convenience perception of $56.4 \%$, while the variation of e-filing usage changes that cannot be explained by perceptions of usefulness and perceptions of convenience but can be explained by other facts that are not observed by researchers is amounted to $43.6 \%$.

This research is also in accordance with research Cahya which states that 1) Perception Usefulness significant effect on the use of e-filing 2) Convenience perception significantly influences the use of e-filing [4]. Likewise with Aulia Dyanrosi's research which states that there are 5 significant relationships, the relationship includes: 1) experience using 2) Attitudes toward use 3) Complexity of use 4) Perception of usefulness. 5) Ease of perception significantly influences the use of efiling.

\section{Conclusion}

Based on the results of data analysis and discussion that has been stated in the previous chapter, then the conclusion that can be taken is the perception of usability toward the behavior has a positive and significant impact on the use of e-filing. This is evidenced by using $t$ test that produces a $\mathrm{t}$ value of 2.733 with a significance level of 0.007 . This means that the higher the perception of usability to the behavior, it can increase the use of e-filing. While the perception of ease of behavior have a positive and significant effect on the use of efiling. This is evidenced by using the $t$ test that produces a $t$ value of 4.489 with a significance level of 0.000 . This means that the higher the perception of ease of behavior, it can increase the use of e-filing.

Based on the results of the $\mathrm{F}$ test or the results simultaneously, the perceptual variables of usability and ease perception together have a positive and significant effect on the use of e-filing. This can be proved from the regression coefficient value of 62.778 with a significance level of 0.000 . This means that the higher the perception of usability and convenience perception, it will increase the use of e-filing.

Based on the result of coefficient of determination test, adjusted value of $\mathrm{R} 2$ in regression model obtained equal to 0.564 . This shows that the influence of perception variable of usability and ease of perception toward e-filing usage variables which can be produced in this equation is $56.4 \%$, while the rest $43.6 \%$ is influenced by other factors not included in this research.

\section{References}

1. Rules Minister Finance Number243/PMK.03/2014 about Letter Annualization (SPT).

2. Anwar Pohan C (2014) Comprehensive Discussion Introduction to Taxation Theory and Concepts of Tax Law. Jakarta: Media Discourse Partners, Jakarta, Indonesia.

3. Dewi Nugraheni A (2015) Factors Affecting Individual Taxpayer Compliance. Diponegoro University, Magelang, Indonesia.

4. Cahya (2013) Analysis Factors Affecting Reception Tax Income Required Individual Taxes, Theses, University Pasundan, Bandung.

5. Ariyanti F (2015) Taxpayers are still afraid to report SPT using E-filing. Jakarta, Sumedang, Indonesia.

6. Mardiasmo (2013) Taxation. Yogyakarta: Andi Publisher.

7. Hardiawan AC (2013) The Influence of Trust, Convenience, and Quality Information To Decision Purchase Online. Essay. Semarang, Universities Diponegoro.

8. Adrianto Sugiarto W (2008) Evaluation Reception Required Tax to Use of E-Filing as Means Reporting Tax on Online and Realtime. Journal Research Accounting in Indonesia, 11: 117-132 University Gajah Mada,Yogyakarta, , Indonesia.

9. Miladia N (2010) Analysis of Factors Affecting Compulsory Tax Compliance Tax Body at Manufacturing Industry Company in Semarang. Essay Faculty Economics, Diponegoro University, Semarang, Indonesia.

10. Ernawati and Purnomosidhi (2010) Influence Attitudes, Subjective Norms, Controls Perceived Behavior, and Sunset Policy against Obedience Required Tax with Intention as Intervening Variables. Essay Polytechnic Negeri Malang and University Brawijaya Jakarta, Indonesia.

11. Faisal Sitompul M (2008) Analysis Against Taxpayer Compliance Level for Submission of E-filing Notification Letter At Tax Office Pratama Medan City, University of North Sumatra Medan, Indonesia.

12. Rules director General Tax No. PER-1 / PJ / 2014 on Delivery Procedures Letter Notice Annual for Individual Taxpayer Using Form 1770S or 1770SS E-filing Through Website Directorate General of Taxation.

13. Rules director General Tax No. PER-26 / PJ / 2012 on Procedures for Reception and Processing Letter Notice.

14. Herman S (2015) Laboratory Data processing. Makassar.

15. Admin (2012) Submission Letter Online Notice (e-Filing). 16: 35.

16. Basu Swastha and Irawan (2007) Management Modern Marketing, Gadjah Mada University, Yogyakarta, Indonesia.

17. Rules Minister Finance Number 74 / PMK.03 / 2012 on Procedures for determination and Revocation Determination Required Tax With Certain Criteria D nature Frame Return preliminary Advantages Payment Tax. 